University of Nebraska - Lincoln

DigitalCommons@University of Nebraska - Lincoln

\title{
Genetic Variation among Canada Wildrye Accessions from Midwest USA Remnant Prairies for Biomass Yield and other Traits
}

\author{
Kenneth P. Vogel \\ University of Nebraska-Lincoln, kvogel1@unl.edu
}

\author{
A. A. Hopkins \\ Samuel Robert Noble Foundation \\ K. J. Moore \\ lowa State University \\ K. D. Johnson \\ Purdue University \\ I. T. Carlson \\ lowa State University
}

Follow this and additional works at: https://digitalcommons.unl.edu/usdaarsfacpub

Vogel, Kenneth P.; Hopkins, A. A.; Moore, K. J.; Johnson, K. D.; and Carlson, I. T., "Genetic Variation among Canada Wildrye Accessions from Midwest USA Remnant Prairies for Biomass Yield and other Traits" (2006). Publications from USDA-ARS / UNL Faculty. 1941.

https://digitalcommons.unl.edu/usdaarsfacpub/1941

This Article is brought to you for free and open access by the U.S. Department of Agriculture: Agricultural Research Service, Lincoln, Nebraska at DigitalCommons@University of Nebraska - Lincoln. It has been accepted for inclusion in Publications from USDA-ARS / UNL Faculty by an authorized administrator of DigitalCommons@University of Nebraska - Lincoln. 


\title{
Genetic Variation among Canada Wildrye Accessions from Midwest USA Remnant Prairies for Biomass Yield and other Traits
}

\author{
K. P. Vogel,* A. A. Hopkins, K. J. Moore, K. D. Johnson, and I. T. Carlson
}

\begin{abstract}
Canada wildrye (Elymus canadensis L.) and Virginia wildrye (Elymus virginicus $L_{\text {.) }}$, which are native to the USA, were collected from remnant Midwest prairies. The objectives of this study were to determine the genetic variability among the collected accessions for biomass yield and other traits, determine the extent of genotype $\times$ environment interactions for these traits across Midwest environments, and to determine the relationship between the geographical location of the collection site and evaluation sites for these accessions for plant biomass yield which can be used as a measure of adaptation. Seed collected from six Midwest states was bulked by collection site to form individual accessions. Space transplanted evaluation nurseries were established at Mead, NE, Ames, IA, and West Lafayette, IN, and accessions were evaluated on a plot basis for 2 yr. There was significant genetic variation among accessions for post-heading forage yield, heading date, height, pre-heading in vitro dry matter digestibility (IVDMD) and crude protein $(\mathrm{CP})$ concentration, and post-heading $\mathrm{CP}$ concentration. Strain $\times$ location $(S \times L)$ interaction effects were only significant for post-heading IVDMD and height indicating that for the other traits, the relative ranking of the strains was similar at all three locations over the two evaluation years. Regression analyses of the effect of distance of the collection site from the evaluation site (direct, east or west, and north or south) on biomass yield were largely nonsignificant or had very low $R^{2}$ values. These regression results along with the nonsignificant $\mathbf{S} \times \mathbf{L}$ effects from the analysis of variance indicate that longitudinal or latitudinal adaptation gradients for plant biomass yield are lacking for Canada wildrye accessions from Midwest prairies. All but five of the Canada wildrye accessions had higher biomass yield than the only released cultivar, Mandan, indicating that this germplasm can be used to develop improved cultivars that should be adapted to the region represented by the collection and evaluation sites.
\end{abstract}

$T$ HERE IS AN INCREASING DEMAND for the use of native plants in conservation and wildlife plantings throughout the USA. Many of the native grasses that have been used for these purposes have been warmseason $\mathrm{C}_{4}$ grasses such as switchgrass (Panicum virgatum L.) and big bluestem (Andropogon gerardii Vitman). Most of the cool-season grasses that are used in the USA for forage, turf, and conservation plantings are introduced grasses such as tall fescue (Festuca arundinacea Schreb.)

K.P. Vogel, USDA-ARS, 344 Keim Hall, Univ. of Nebraska, P.O. Box 830937, Lincoln, NE 68583-0937; A.A. Hopkins, The Samuel Robert Noble Foundation, 2510 Sam Noble Parkway, Ardmore, OK 73401; K.J. Moore, 1571 Agronomy Hall, Iowa State Univ., Ames, IA 500111010; K.D. Johnson, 1150 Lilly Hall, Purdue Univ., West Lafayette, IN 47907-2054; I.T. Carlson, 2101 Agronomy Hall, Iowa State Univ., Ames, IA 50011-1010 (retired Professor of Agronomy). Mention of a trade name does not constitute a guarantee of the product by USDA or the University of Nebraska and does not imply its approval to the exclusion of other suitable products. Received 12 Jan. 2006. *Corresponding author (kpv@unlserve.unl.edu).

Published in Crop Sci. 46:2348-2353 (2006).

Plant Genetic Resources

doi:10.2135/cropsci2006.01.0020

(c) Crop Science Society of America

677 S. Segoe Rd., Madison, WI 53711 USA and smooth bromegrass (Bromus inermis Leyss.). The tallgrass prairie region of North America occupied over $500000 \mathrm{~km}^{2}$ of central North America in what is now the north-central states or Corn Belt region of the USA (Risser et al., 1981). Currently, only remnants of the original prairie remain.

Canada wildrye is a cool-season $\left(\mathrm{C}_{3}\right)$ grass that is native to most of the continental USA (Hitchcock, 1971; Barkley, 1986). It was one of the prevalent cool-season grasses in the tallgrass prairie region of the USA. It is a tetraploid species $(2 n=4 x=28)$ and is largely selfpollinated (Sanders and Hamrick, 1980; Jensen et al., 1990). Virginia wildrye is another native cool-season grass that was found in most continental USA states except for California, Oregon, and Nevada (Hitchcock, 1971; Barkley, 1986). Virginia wildrye was typically found in moist, low ground along woods and streams. Canada wildrye has long awns $(2$ to $3 \mathrm{~cm}$ ) while Virginia wildrye has short awns (about $1 \mathrm{~cm}$ in length) on their lemmas. Both species have the same number of chromosomes and are fertile when hybridized (Church, 1958). Hybrids between E. canadensis and E. virginicus have normal meiosis and produce viable, variable progeny (Church, 1958). Plants in native stands that resemble the hybrid progeny of E. canadensis and E. virginicus have been classified as E. virginicus var. submuticus Hook. or have been given other E. virginicus varietal designations (Hitchcock, 1971; Church, 1958; Barkley, 1986). These interspecific plants and populations have been found throughout the range of where the two species are found growing in association (Church, 1958; Pohl, 1959; Nelson and Tyrl, 1978).

To date, one cultivar each of Canada wildrye and Virginia wildrye has been released or developed. Mandan Canada wildrye was developed from collections made near Mandan, ND (Alderson and Sharp, 1994). Omaha wildrye is a privately developed Virginia wildrye cultivar that is produced by Stock Seed Farms, Murdock, NE. It originates from plant material collected in eastern Nebraska. Recently, accessions of Virginia wildrye originating in northeastern USA were evaluated at three locations in that region for forage yield, persistence, and plant morphology in space transplanted trials (Sanderson et al., 2004a). Two orchardgrass (Dactylis glomerata L.) cultivars and Omaha were included as checks. There were differences among wildryes for most traits depending on the year and location. The two orchardgrass cultivars outyielded the wildryes over years and locations and had better persistence. The forage quality of the Virginia wildrye accessions was similar to that of other cool-season grasses at similar stages of maturity (Sanderson et al., 2004b). The authors' conclusion was that the most viable

Abbreviations: CP, crude protein; IVDMD, in vitro dry matter digestibility; PAR, Plant Adaptation Regions. 
use for Virginia wildrye would be in conservation plantings rather than for forage purposes.

The tallgrass prairie region of North America is classified as the Prairie Parkland (Temperate) ecoregion province in the widely used ecoregion classification system developed by Bailey $(1995,1997,1998)$. Vogel et al. (2005) overlaid Bailey's ecoregion province classification system with the USDA Plant Hardiness Zone Map (Cathey, 1990) to develop Plant Adaptation Regions (PAR) which integrate the ecological and climatic variables that affect plant adaptation in a region.

Canada wildrye and Virginia wildrye accessions were collected from remnant prairies in this region in the autumn of 1989 (Vogel et al., 1992). The objectives of this research were to determine the genetic variability among the collected accessions for agronomic traits, determine the extent of genotype $\times$ environment interactions for these traits across Midwest environments, and to determine the relationship between the geographical location of the collection site and evaluation sites for these accessions for plant adaptation as measured by biomass yield. Plant biomass yield or plant size has been used in ecological studies as a measure of plant adaptation to a site (Byers, 1998; Montalvo and Ellstrand, 2001; Gustafson et al., 2004). Plant Adaptation Regions will be used in this report to describe both the wildrye assession's collection and evaluation sites.

\section{MATERIALS AND METHODS}

In this report, site refers to the area from which the seed was collected, location refers to the three areas where the evaluation trials were transplanted, and $\operatorname{strain}(s)$ refers to the individual accessions or cultivars that were included in the research. Strains identified as ACMO, HCMO, and MO followed by a number were from Missouri. The first two letters of the strain designation is the postal code for the state origin of the remaining strains. Within a state, accessions were designated by the numerically coded site from which they were collected, for example, accession NE3 was from Nebraska prairie site 3.

Seed was collected from Canada wildrye plants and from plants of nonbearded Virginia wildrye plants that phenotypically were similar to the botanical description of E. virginicus var. submuticus. These are described in this report as the Canada wildrye (C) or Virginia wildrye (V) phenotypes. The collections were made in the autumn of 1989 from remnant prairie sites (Fig. 1, Table 1) in the north-central USA (Vogel et al., 1992; Hopkins et al., 1995; Vinton et al., 2001). The accession IL62 was collected from a restored prairie planted in 1940; all other accessions originated from unplanted, native prairie sites. The collection sites are representative of the remnant prairie sites that exist in the region. At each site, spikes were collected from throughout the remnant site in a random manner. Seed from all the spikes from a site were bulked and threshed. Bulked seed was given an accession number that identified both the accession and the collection site.

Seed from each accession was wet chilled for $3 \mathrm{wk}$ at $4.5^{\circ} \mathrm{C}$ and planted in the greenhouse into plastic seedling tubes $(22 \mathrm{~cm}$ deep and $4 \mathrm{~cm}$ in diameter) which contained a mixture of 2:1:1 soil/peat/vermiculite. After emergence, seedlings were thinned to one seedling per tube. Seedlings of the accessions and the check cultivar Mandan Canada wildrye were transplanted into single-row plots at the three field evaluation sites which were near Mead, NE, Ames, IA, and West Lafayette, IN. Soil type was Sharpsburg silt loam (fine, smectitic, mesic Typic Argiudoll) at Mead, Webster silty clay loam (fine-loamy, mixed, superactive, mesic Typic Endoaquoll) at Ames, and Xenia silt loam (fine-silty, mixed, superactive, mesic Aquic Hapludalf) at West Lafayette. Climatic conditions at the three sites for the

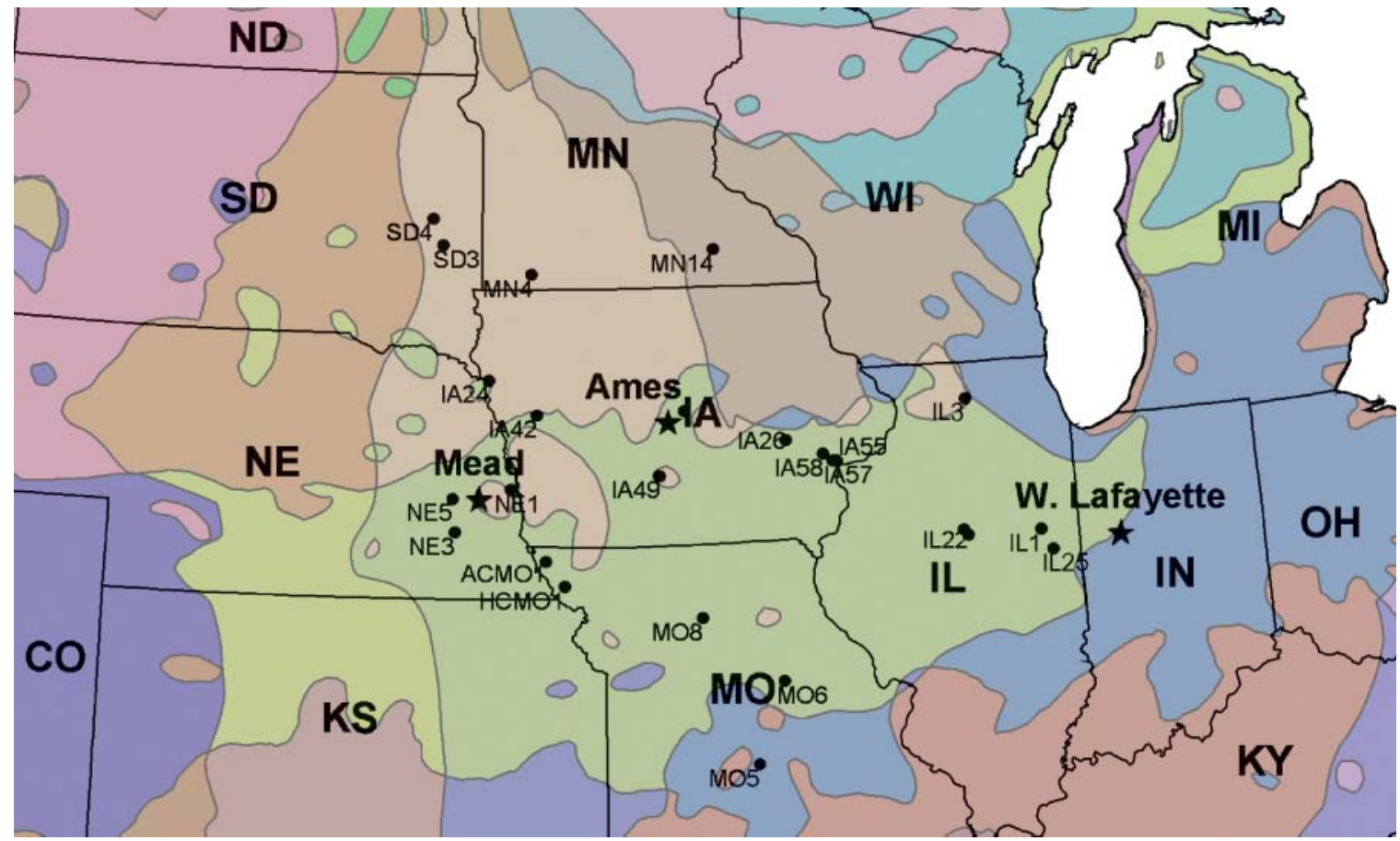

Fig. 1. Plant Adaptation Regions (colored regions), Canada wildrye collection sites $(\bullet)$, and evaluation locations (star) for Canada wildrye accessions collected from remnant Midwest prairies. Plant Adaptation Regions are: light green, PAR 251-5 (Temperate Prairie Parkland, Plant Hardiness Zone 5); tan, PAR 251-4; light brown, PAR 222-4 (Eastern broadleaf forest, Plant Hardiness Zone 4); blue, PAR 222-5. 
Table 1. Canada and Virginia wildrye accession or strain means averaged over three Midwest locations (Mead, NE, Ames, IA, and West Lafayette, IN) for biomass yield and other traits.

\begin{tabular}{|c|c|c|c|c|c|c|c|c|}
\hline \multirow[b]{2}{*}{ Strain } & \multirow[b]{2}{*}{ Type $\dagger$} & \multirow[b]{2}{*}{ Yield } & \multirow[b]{2}{*}{ Heading date } & \multirow[b]{2}{*}{ Spike height } & \multicolumn{2}{|c|}{ Pre-heading } & \multicolumn{2}{|c|}{ Post-heading } \\
\hline & & & & & IVDMD $\%$ & $\mathrm{CP}+$ & IVDMD & $\mathbf{C P}$ \\
\hline & & g plant $^{-1}$ & DOY $\ddagger$ & cm & 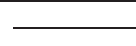 & $-\mathbf{g}$ & & \\
\hline ACMO1 & C & 676 & 201 & 130 & 651 & 144 & 497 & 93 \\
\hline ACMO1L & C & 671 & 179 & 138 & 599 & 152 & 474 & 86 \\
\hline HCMO1 & $\mathbf{C}$ & 455 & 197 & 122 & 699 & 159 & 508 & 97 \\
\hline MO5 & $\mathrm{C} / \mathrm{V}$ & 141 & 183 & 90 & 645 & 172 & 451 & 108 \\
\hline MO6 & C & 117 & 189 & 101 & 644 & 162 & 451 & 110 \\
\hline M06А & $\mathbf{V}$ & 259 & 184 & 88 & 623 & 157 & 456 & 105 \\
\hline MO8 & $\mathbf{V}$ & 330 & 182 & 111 & 614 & 151 & 429 & 99 \\
\hline IA24 & C & 608 & 200 & 134 & 690 & 166 & 496 & 100 \\
\hline IA26 & $\mathrm{C} / \mathrm{V}$ & 335 & 190 & 98 & 636 & 168 & 481 & 110 \\
\hline IA42 & C & 646 & 198 & 126 & 676 & 161 & 498 & 97 \\
\hline IA49 & $\mathbf{C}$ & 431 & 197 & 132 & 700 & 158 & 465 & 96 \\
\hline IA50A & $\mathbf{V}$ & 403 & 189 & 79 & 653 & 158 & 497 & 96 \\
\hline IA55 & C & 241 & 182 & 98 & 640 & 165 & 461 & 104 \\
\hline IA57A & $\mathbf{V}$ & 374 & 188 & 104 & 620 & 157 & 481 & 113 \\
\hline IA58 & $\mathbf{C} / \mathrm{V}$ & 465 & 191 & 134 & 659 & 162 & 489 & 90 \\
\hline MN14 & C & 464 & 197 & 110 & 671 & 168 & 499 & 100 \\
\hline MN4 & C & 472 & 193 & 94 & 711 & 167 & 488 & 100 \\
\hline IL1 & C & 488 & 190 & 110 & 651 & 160 & 454 & 91 \\
\hline IL21 & $\mathrm{C} / \mathrm{V}$ & 527 & 202 & 96 & 655 & 182 & 526 & 121 \\
\hline IL22 & C & 498 & 196 & 124 & 681 & 179 & 498 & 103 \\
\hline IL25 & $\mathbf{V}$ & 223 & 189 & 74 & 660 & 159 & 482 & 112 \\
\hline IL 3 & $\mathbf{C}$ & 469 & 176 & 117 & 654 & 153 & 475 & 93 \\
\hline IL62 & C & 565 & 193 & 130 & 682 & 163 & 514 & 96 \\
\hline NE1 & C & 463 & 196 & 118 & 668 & 149 & 478 & 93 \\
\hline NE3 & $\mathbf{C}$ & 484 & 190 & 125 & 667 & 151 & 487 & 97 \\
\hline NE5 & C & 517 & 186 & 124 & 660 & 154 & 482 & 94 \\
\hline SD3 & $\mathbf{C}$ & 160 & & 70 & 667 & 234 & 504 & 123 \\
\hline SD4 & C & 390 & 190 & 92 & 707 & 192 & 559 & 117 \\
\hline Mandan & C & 286 & 179 & 103 & 677 & 172 & 489 & 107 \\
\hline LSD 05 & & 225 & 11 & 18 & 56 & 17 & ns & 15 \\
\hline \multicolumn{9}{|l|}{ Means } \\
\hline Overall & & 431 & 190 & 111 & 661 & 163 & 485 & 101 \\
\hline Ames, IA & & 322 & 190 & 104 & 597 & 129 & 459 & 98 \\
\hline Mead, NE & & 401 & 194 & 109 & 676 & 174 & 472 & 95 \\
\hline W. Lafayette, IN & & 566 & 188 & 120 & 711 & 184 & 522 & 110 \\
\hline
\end{tabular}

$\dagger C, E$. canadensis accession; $V, E$. virginicus accession; $C / V$, accession contained both types.

$\$$ DOY, day of the year; IVDMD, in vitro dry matter digestibility; CP, crude protein.

duration of the trial are summarized in Table 2. The experimental design was a randomized complete block (RCB) with two replicates or blocks at each location. A plot consisted of a single row of 10 plants at Mead and Ames and 7 plants at West Lafayette. Plants within a row and rows were spaced $1.1 \mathrm{~m}$ apart.

During the establishment and post-establishment years, herbicides and hand weeding were used for weed control and the nurseries were essentially free of weeds. The herbicides, rates, and application dates varied with location and year but typically included herbicides for pre-emergence control of both

Table 2. Climatic data, with deviations from average, for the 1991 and 1992 growing seasons at Mead, NE, Ames, IA, and West Lafayette, $\mathbf{I N} \cdot \dagger$

\begin{tabular}{|c|c|c|c|c|}
\hline \multirow[b]{2}{*}{ Location } & \multicolumn{2}{|c|}{ Seasonal precipitation } & \multicolumn{2}{|c|}{ Monthly temperature } \\
\hline & Total & Deviation & Average & Deviation \\
\hline & 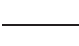 & & $\longrightarrow$ & $8-$ \\
\hline \multicolumn{5}{|l|}{1991} \\
\hline Mead $\$$ & 58.9 & -9.3 & 18.9 & 0.3 \\
\hline Ames & 75.3 & 9.9 & 18.0 & 0.7 \\
\hline West Lafayette & 51.4 & -13.9 & 19.1 & 1.5 \\
\hline \multicolumn{5}{|l|}{1992} \\
\hline Mead & 42.0 & -20.0 & 17.5 & -2.2 \\
\hline Ames & 55.9 & -3.6 & 17.0 & -1.4 \\
\hline West Lafayette & 63.4 & 4.6 & 16.9 & $-\mathbf{1 . 5}$ \\
\hline
\end{tabular}

$\uparrow$ Growing seasons were April to October 1991 and April to September 1992. $\ddagger$ Nearest reporting stations with complete precipitation (Wahoo, NE) and temperature (Ashland, NE) data were used for Mead. grassy and broadleaf weeds that was applied in the spring each year. The nurseries were fertilized with $112 \mathrm{~kg} \mathrm{ha}^{-1} \mathrm{~N}$ as ammonium nitrate in April or early May of 1991 and 1992 at each location. No fertilizers were applied the establishment year.

No data were collected during the 1990 establishment year. The plots were evaluated for stands, biomass yield, heading date, spike height, and forage quality traits in 1991 and 1992. Stand data were obtained by counting the number of surviving plants in a row. Heading date was the date on which the majority of the plants in a plot had three or more heads exerted from the flag leaf. Accessions were identified as having the $\mathrm{C}$ or $\mathrm{V}$ phenotype before forage harvest by the senior author. Vegetative samples were collected before heading in late April or May at each location while post-heading samples were collected just before forage biomass harvest in July or early August. Post-heading samples and harvests at the West Lafayette site were collected as plants headed, while at Mead and Ames the samples were collected and forage harvests were made after all accessions in the nurseries had headed. At both sampling periods, samples were collected by cutting three to four tillers, at approximately $10 \mathrm{~cm}$ of height, from each plant within a plot. Samples were dried in forced-draft ovens at $50^{\circ} \mathrm{C}$ $\left(60^{\circ} \mathrm{C}\right.$ at West Lafayette) to determine dry matter concentration of the samples which were used to adjust forage biomass yields to a dry weight basis. Plots were harvested at a height of $10 \mathrm{~cm}$ using a flail plot harvester. The dry weight of the forage samples collected for dry matter and quality analysis was added to the plot forage yield. The number of plants in each plot at harvest was determined and forage yield was expressed 
as dry weight per plant by dividing plot yield by the number of harvested plants per plot. This was necessary because some seedlings died after transplanting in the establishment year. Stands were stable at all three sites after the establishment summer. Subsequent stand losses were so minimal that analysis for stand loses was not conducted.

\section{Forage Quality Analyses}

The dried forage samples were ground in a Wiley shear mill to pass a 1-mm screen and reground to uniformity in a cyclone impact mill. All samples were scanned using a near infrared reflectance spectrophotometer (NIRS; Technicon Infralyzer 500, Bran \& Luebbe Analyzing Technologies, Buffalo Grove, IL) over a wavelength range of 1100 to $2500 \mathrm{~nm}$ with 2-nm steps. Development and verification of prediction equations for IVDMD on wet lab values were as described by Hopkins et al. (1995). Crude protein concentration $(\mathrm{N} \times 6.25)$ was determined by the University of Nebraska Agronomy Department Analytical Laboratory using the Kjeldahl procedure. NIRS prediction equations were developed for forage protein concentrations using the same NIRS calibration procedures as for IVDMD. The prediction equations for IVDMD and CP had $R^{2}$ values of 0.96 and 0.94 , respectively and the standard error of calibration (SEC) was 2.13 and 1.06, respectively, for the two traits.

\section{Statistical Analyses}

Because the wildrye accessions were perennials, data were analyzed across years as a split plot in time with strains as whole plots, years as split plots, and blocks nested within locations (Hicks, 1973). Populations or strains were considered to be fixed effects and years, replications, and locations were assumed to be random effects. The method of Neter et al. (1985) was used to calculate approximate $F$ values and approximate degrees of freedom were calculated according to Satterthwaite (1946). Regression analysis was conducted to determine if the distance of the collection site from the evaluation site had an effect on individual plant biomass yield. A Cartesian grid was placed over a map on each of the three evaluation sites and the distance north $(+)$, south $(-)$, east $(+)$, or west $(-)$ of the collection site from the evaluation site was determined. Regression analysis was done for the effect of direct distance, north or south distance, and east or west distance on individual plant biomass yield. This analysis was completed using only Canada wildrye accessions from sites known to be true remnant prairies (Fig. 1). All data were analyzed using SAS software (SAS Institute, 1999).

\section{RESULTS AND DISCUSSION}

The wildryes evaluated in this report were largely collected from Plant Hardiness Zones 4 and 5 of the temperate Prairie Parkland ecoregion province (PAR 251-4 and PAR 251-5, respectively) although two accessions, MN14 and MO 5, were collected from PARs 222-4 and 222-5 (Eastern Deciduous Forest, Hardiness Zones 4 and 5, respectively; Fig. 1). The evaluation site at Mead, $\mathrm{NE}$, is in the western part of the Praire Parkland ecoregion province and is on the boundary of Plant Hardiness Zones 4 and 5. The West Lafayette site is on the boundary of the Prairie Parkland and Eastern Deciduous Forest provinces and is in Plant Hardiness Zone 5. The Ames, IA, site is typical of the Prairie Parkland province and is in Plant Hardiness Zone 5. The environmental conditions during the evaluation period at the three locations were representative of the environmental variation that exists in the temperate Prairie Parkland ecoregion over years (Table 2). Annual precipitation was substantially below the long-term average in both 1991 and 1992 at Mead, NE, and in 1991 at West Lafayette. Precipitation at Ames in 1991 was almost $10 \mathrm{~cm}$ above normal. Temperatures were somewhat warmer and cooler than normal, respectively, in 1991 and 1992 at the three locations.

Accessions that were evaluated included both $\mathrm{C}$ and $\mathrm{V}$ phenotypes (Table 1 ). The $\mathrm{V}$ phenotypes were almost entirely similar to the plants produced by hybridization of Canada wildrye and Virginia wildrye and described botanically as varieties of Virginia wildrye (Hitchcock, 1971; Church, 1958; Barkley, 1986). Because they were found growing in proximity with the Canada wildryes and since they were likely part of the wildrye germplasm complex at a prairie site, the Virginia wildrye strains were included in the evaluation trials with true Canada wildrye strains.

There was significant variation among accessions or strains when evaluated over years and evaluation sites for forage biomass yield, heading date, height, preheading IVDMD, and protein concentration (Tables 1 and 3 ). Strain $\times$ location interaction affects were not significant for forage biomass yield, heading dates, preheading IVDMD, or protein concentration. This indicates that the relative values of the strains were similar at all three locations over the two evaluation years for these traits. There were significant strain $\times$ location interaction effects for post-heading IVDMD which were probably due to the West Lafayette samples being collected as strains matured while the samples at the other two sites were all collected at a single harvest date. There were significant strain $\times$ location interaction effects for height but the mean square for the strain effect was 10 times that of the strain $\times$ location effect and the $\sigma^{2}$ for stains was about 5 times the $\sigma^{2}$ for strains $\times$ locations (data not shown) indicating their relative importance. Because strain $\times$ location effects were not significant for most traits or of minor importance, only over-location means are reported.

Some of the collected accessions contained mixtures of plants with the $\mathrm{C}$ or $\mathrm{V}$ phenotypes. These strains and the strains that were classified as E. virginicus or $\mathrm{V}$ phenotypes were within the range of means for forage biomass yield, digestibility, and crude protein content of the Canada wildrye stains both when compared to all accessions and to accessions collected in the same state. The Virgina wildrye accessions typically were shorter in stature than the Canada wildrye accessions. In production agriculture, the only apparent merit that the E. virginicus accessions would have in comparison to Canada wildrye accessions is that their short awns would make seed harvest and processing easier.

There were significant differences among accessions over locations for biomass yield which was consistent over all test locations (Table 3). All but five of the accessions had higher biomass yield than the Canada wild- 
Table 3. Mean squares from the analysis of variance for biomass yield and other traits for Canada and Virginia wildrye accessions or strains collected from remnant Midwest USA prairies and evaluated at three Midwest sites.

\begin{tabular}{|c|c|c|c|c|c|c|c|c|}
\hline \multirow[b]{2}{*}{ Source } & \multirow[b]{2}{*}{ df } & \multirow[b]{2}{*}{ Biomass yield } & \multirow[b]{2}{*}{ Heading date } & \multirow[b]{2}{*}{ Height } & \multicolumn{2}{|c|}{ Pre-heading } & \multicolumn{2}{|c|}{ Post-heading } \\
\hline & & & & & IVDMD $\dagger$ & $\mathbf{C P} \dagger$ & IVDMD & $\mathbf{C P}$ \\
\hline & & g plant $^{-1}$ & DOY $\dagger$ & cm & 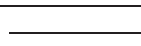 & - & & \\
\hline Location & 2 & 1640231 & 1241 & 7932 & 327980 & 83830 & 112820 & 6280 \\
\hline Strain & 28 & 199738 & 531 & 3873 & 8600 & 1420 & 7001 & 840 \\
\hline Replicate (L)† & 3 & 207016 & 79 & 173 & 8350 & 600 & 1480 & 320 \\
\hline $\mathbf{L} \times \mathbf{S} \dagger$ & 54 & 49380 & 140 & 389 & 2440 & 260 & 2330 & 180 \\
\hline $\mathbf{S} \times \mathbf{R}(\mathbf{L}) \neq \dagger$ & 80 & 19663 & 108 & 89 & 1780 & 140 & 1130 & 180 \\
\hline Year & 1 & 11771 & 14780 & 27248 & 176840 & 230 & 456420 & 5260 \\
\hline $\mathbf{L} \times \mathbf{Y} \doteqdot$ & 2 & 561899 & 554 & 7675 & 243840 & 25790 & 35660 & 5460 \\
\hline $\mathbf{Y} \times \mathbf{R}(\mathbf{L})$ & 3 & 4109 & 118 & 16 & 3220 & 70 & 2460 & 40 \\
\hline $\mathbf{S} \times \mathbf{Y}$ & 27 & 50891 & 154 & 200 & 3650 & 330 & 3420 & 300 \\
\hline $\mathbf{L} \times \mathbf{S} \times \mathbf{Y}$ & 53 & 26521 & 112 & 126 & 1500 & 170 & 1090 & 140 \\
\hline Error & 69 & 13527 & 115 & 65 & 1800 & 150 & 1320 & 160 \\
\hline$F$ for strain & & $2.71 * *$ & $2.92 * *$ & $8.37 * *$ & $1.87 *$ & 3.38 *** & 1.50 & $2.47 * *$ \\
\hline$F$ for $S \times L$ & & 1.51 & 1.33 & $2.59 * *$ & 1.65 & 1.63 & $2.59 * *$ & 1.13 \\
\hline$F$ for $S \times Y$ & & $1.92 *$ & 1.38 & 1.59 & $2.43 *$ & $1.94^{*}$ & 3.15* & 2.14** \\
\hline
\end{tabular}

* Indicates significance at the 0.05 level of probability.

** Indicates significance at the 0.01 level of probability.

$\dagger$ IVDMD, in vitro dry matter digestibility; CP, crude protein; DOY, day of the year.

$\doteqdot \mathrm{L}$, location; $\mathrm{S}$, strain; $\mathbf{R}$, replicate; $\mathrm{Y}$, year.

rye cultivar Mandan that was included in the study as a control. Because of the stability for yield of Canada wildrye strains across the broad evaluation area, it should be feasible to use the highest yielding accessions to develop new cultivars of Canada wildrye for use in the PARs 251-4 and 251-5 that will be superior to Mandan. The difference in pre-heading IVDMD and crude protein concentration among strains may be influenced by differences in maturity but this cannot be tested because we did not stage the plants for maturity when the vegetative samples were collected. There were no significant differences among strains for IVDMD when post-heading samples were analyzed. Based on the range in values, heritable differences among the wildrye accessions for IVDMD likely exist but it will take additional trials with more replicates to identify strains with high IVDMD. Significant differences in CP concentration existed among strains at both harvests suggesting that it should be feasible to develop Canada wildrye cultivars with improved crude protein concentration.

Regression analysis was used to determine the relationship between distance of the collection site from the evaluation site and accession biomass yield. There were no significant effects of direct distance of the evaluation site from the collection site for the three evaluation sites (Table 4). The north to south and east to west distance of the evaluation site from the collection site were not significant for either Mead, NE, or West Lafayette, IN. There were significant differences for north to south and east to west distances of the collection site from the evaluation site for the Canada wildrye accessions evaluated at Ames, IA, but the regression equations had relatively low $R^{2}$ values indicating low predictability. Based on the sign and magnitude of the regression coefficients ( $b$ values), the farther north a strain was collected from Ames, the higher its yield was at Ames and opposite for strains originating south of Ames (Table 4). The farther west an accession was collected from Ames, the higher its yield was at Ames and the opposite for strains collected east of Ames. The effect of distance of collection site distance from Ames ranged from 0.28 to $0.44 \mathrm{~g} \mathrm{~km}^{-1}$ which is very small considering the magnitude of differences for biomass yield.

The regression results demonstrate that although Canada wildrye accessions from Midwest prairies differ significantly for biomass yield, there is a low or nonsignificant association between germplasm origin and test site location for biomass yield over a broad geographical area. These regression results are supported by the over-locations analysis of variance that showed that strain $\times$ location effects were not significant for biomass yield. These results indicate that Canada wildrye accessions from Midwest Prairies are adapted to a broad geographical area and the best plant material can be used throughout the region represented by the collection and evaluation sites.

The utility of improved strains of Canada wildrye in grassland production systems in the Midwest will need to be determined in sward trial comparisons with smooth bromegrass and other cool-season grass cultivars currently being used in the region for pastures. A portion of the Canada wildrye accessions were evaluated in space transplanted seed increase nurseries for the presence of endophytic fungi (genus Neotyphodium) by Vinton et al.

Table 4. Regression statistics for the regression of biomass yield (g plant ${ }^{-1}$ ) on the distance and directional distance between evaluation locations and collection sites for Canada wildrye germplasm accessions collected and evaluated in the Midwest, USA.

\begin{tabular}{|c|c|c|c|c|}
\hline Distance type $\dagger$ & Statistic & Mead, NE & Ames, IA & W. Lafayette, IN \\
\hline \multirow[t]{2}{*}{ Direct vector } & $R^{2}$ & 0.05 & $\mathbf{0 . 0 5}$ & 0.04 \\
\hline & b & -0.14 & -0.25 & 0.18 \\
\hline \multirow[t]{2}{*}{ North-south } & $R^{2}$ & 0.05 & $0.26^{*}$ & 0.09 \\
\hline & $b$ & 0.19 & $0.44 *$ & 0.40 \\
\hline \multirow[t]{2}{*}{ East-west } & $R^{2}$ & $\mathbf{0 . 0 2}$ & 0.19* & 0.05 \\
\hline & $b$ & -0.07 & $-0.28 *$ & -0.21 \\
\hline
\end{tabular}

* Indicates significance at the 0.05 level of probability.

$\uparrow$ North to south and east to west distance is the distance $(\mathbf{k m})$ north $(+)$, south $(-)$, east $(+)$, or west $(-)$ of the collection site from the evaluation site; direct vector is the distance between evaluation and collection site. $+n=23$ for each site. 
(2001). The endophyte was found in all of the accessions that were evaluated. The effect of the endophyte on ruminants will need to be determined in grazing trials if Canada wildrye appears to be competitive with bromegrass and orchardgrass in the sward trials. The use of Canada wildrye in conservation plantings will continue but these results indicate that broadly adapted cultivars can be used for these plantings in the Midwest. Virginia wildrye strains may be useful in increasing the botanical diversity in conservation plantings.

\section{REFERENCES}

Alderson, J., and W.C. Sharp. 1994. Grass varieties in the United States. Agricultural Handbook No. 170. Soil Conserv. Serv., USDA, Washington, DC.

Bailey, R.G. 1995. Description of the ecoregions of the United States 2nd ed. rev. and expanded (1st ed. 1980). Misc. Publ. No. 1391 (rev). U.S. Forest Service, Washington, DC.

Bailey, R.G. 1997. Map: Ecoregions of North America (rev.) [Online]. Available at www.fs.fed.us/colorimagemap/ecoreg1_provinces (verified 2 Aug. 2006). USDA Forest Service in cooperation with The Nature Conservancy and the U.S. Geological Survey. U.S. Forest Service, Washington, DC.

Bailey, R.G. 1998. Explanatory note for ecoregions map. Misc. Publ. 1548. U.S. Forest Service, Washington, DC

Barkley, T.M. (ed.) 1986. Flora of the Great Plains. Univ. Press of Kansas, Lawrence, KS

Byers, D.L. 1998. Effect of cross proximity on progeny fitness in a rare and a common species of Eupatorium (Asteraceae). Am. J. Bot. 85:644-653

Cathey, H.M. 1990. USDA Plant Hardiness Zone Map. USDA Misc. Pub. No. 1475. U.S. Natl. Arboretum, ARS, USDA, Washington, DC (2004 U.S. Natl. Arboretum Web Version [Online]. Available at www.usna.usda.gov/Hardzone/ushzmap.html [verified 7 Aug. 2006])

Church, G.L. 1958. Artificial hybrids of Elymus virginicus with E. canadensis, interuptus, riparius, and wregundii. Am. J. Bot. 45:410-417.

Gustafson, D.J., D.J. Gibson, and D.L. Nickrent. 2004. Competitive relationships of Andropogon gerardii (Big bluestem) from remnant and restored native populations and select native cultivars. Funct Ecol. 8:451-457.

Hicks, C.R. 1973. Nested and nested factorial analysis. p. 227-251. In
Fundamental concepts in the design of experiments. Holt, Rinehart, and Winston Co., New York.

Hitchcock, A.S. 1971. Manual of the grasses of the United States. 2nd ed. Dover Publ., Inc., New York.

Hopkins, A.A., K.P. Vogel, K.J. Moore, K.D. Johnson, and I.T. Carlson. 1995. Genetic variability and genotype $\times$ environment interactions among switchgrass accessions from the midwestern USA. Crop Sci. 35:565-571.

Jensen, K.B., Y.F. Zhang, and D.R. Dewey. 1990. Mode of pollination of perennial species of the Tribe Triticeae in relation to genomically defined genera. Can. J. Plant Sci. 70:215-225.

Montalvo, A.M., and N.C. Ellstrand. 2001. Nonlocal transplantation and outbreeding depression in the subshrub Lotus scoparius (Fabaceae). Am. J. Bot. 88:258-269.

Nelson, E.N., and R.J. Tyrl. 1978. Hybridization and introgression between Elymus canadensis and Elymus virginicus (Poaceae). Proc. Okla. Acad. Sci. 58:32-34.

Neter, J., W. Wasserman, and M.H. Kutner (ed.). 1985. Applied linear statistical models. 2nd ed. Richard D. Irwin, Inc. Homewood, IL.

Pohl, R.W. 1959. Morphology and cytology of some hybrids between Elymus canadensis and E. virginicus. Iowa Acad. Sci. 66:155-159.

Risser, P.G., E.C. Birney, H.D. Blocker, S.W. May, W.J. Parton, and J.A. Wiens. 1981. The true prairie ecosystem. Huchinson Ross Publishing C., Stroundsburg, PA.

Sanders, T.B., and J.L. Hamrick. 1980. Variation in the breeding system of Elymus canadensis. Evolution 34:117-122.

Sanderson, M.A., R.H. Skinner, J. Kujawski, and M. van der Grinten. 2004a. Virginia wildrye evaluated as a potential native cool-season forage in the Northeast USA. Crop Sci. 44:1379-1384.

Sanderson, M.A., R.H. Skinner, M. van de Grinten, and J. Kujawski. 2004b. Nutritive value of Virginia wildrye, a cool-season grass native to the Northeast USA. Crop Sci. 44:1385-1390.

SAS Institute. 1999. The SAS OnLine Doc v. 8. SAS Inst., Cary, NC.

Satterthwaite, F.E. 1946. An approximate distribution of estimates of variance components. Biometrics 2:110-114.

Vinton, M.A., E.S. Kathol, K.P. Vogel, and A.A. Hopkins. 2001 Endophytic fungi in Canada wildrye in natural grasslands. J. Range Manage. 54:390-395.

Vogel, K.P., K.J. Moore, A.A. Hopkins, and A.J. Vybiral. 1992. Germsplasm resources of the North American tallgrass prairie. p. 207. In Agronomy Abstracts. ASA, Madison, WI.

Vogel, K.P., M.R. Schmer, and R.B. Mitchell. 2005. Plant Adaptation Regions: Ecological and climatic classification of plant materials. Rangeland Ecol. Manage. 58:315-319. 